\title{
Serum lactate dehydrogenase level in childhood acute lymphoblastic leukemia
}

\author{
Md. Golam Hafiz and M.A. Mannan \\ Department of Pediatric Hematology and Oncology, \\ Bangabandhu Sheikh Mujib Medical University, Shahbag, Dhaka, Bangladesh.
}

\begin{abstract}
Serum lactate dehydrogenase (LDH) level was estimated in 44 childhood (age range 1-15 years) acute lymphoblastic leukemia (ALL) on admission, day 14 and day 29 of induction. Another 25 children without ALL were included as control. On admission, the level of serum LDH was significantly high in ALL cases than control $(\mathrm{p}<0.001)$. Total WBC count was significantly decreased along with serum LDH level at day 14 and day 29 of induction $(\mathrm{p}<0.001)$. A significant rise of platelet count was observed at day 29 of induction in relation to significant decrease of serum LDH level $(\mathrm{p}<0.001)$. A significant decrease of peripheral and bone marrow blast cell percentages were also observed at day 29 of induction along with significant decrease level of serum LDH $(\mathrm{p}<0.001)$. So, the measurement of serum LDH level can be accepted as an enzymatic tool for presumption of childhood ALL and the response to chemotherapy during induction of remission.
\end{abstract}

\section{Introduction}

Leukemia is characterized by persistent and enormous production of immature white blood cell. It is responsible for an overwhelming majority of the childhood malignancies. The incidence of leukemia in various pediatric centers in India varies from 0.3 to $1.2 \%{ }^{1}$. Acute lymphoblastic leukemia (ALL) in children is a highly curable disease. Nowa-days, the cure rate in western countries lies between $70-80 \%{ }^{2}$. In Bangladesh, though exact incidence is unknown, there appears to be an increase in the case of childhood malignancies. Yet if we take the cognizance of incidence of other countries of this region we can presume that 5 to 6 thousands new cases should diagnosed each year ${ }^{3}$.

There is a good relationship between neoplasia and increased serum lactate dehydrogenase (LDH) level. LDH level is moderately elevated in many cases of acute leukemia, irrespective of their cell type. Markedly elevated level of $\mathrm{LDH}$ is recorded in the majority of patients with ALL and is suggestive of increased cell proliferation and turnover ${ }^{4}$. It is thought that the determination of serum LDH activity has received attention in several medical centers both as an investigative tool and as clinical laboratory procedures because of the promise that it has shown in the diagnosis and prognosis of childhood $\mathrm{ALL}^{5}$. Quantitative biochemical estimation of serum LDH provides a simpler and more objective measurement of tumor volume. Such measurement should be included in the evaluation of patients with $\mathrm{ALL}^{6}$.

Higher serum LDH level is associated with higher leukocytes counts, lower blast cell DNA indices, lower platelet count and a larger spleen size. Patient with highest LDH level (greater than $1000 \mathrm{U} / \mathrm{l}$ ) is most likely to be non-responsive to treatment, whereas those with lowest level (less than 300 IU/l) have the minimum risk of failure of treatment. The measurement of serum $\mathrm{LDH}$ is useful in risk assessment or stratification of ALL patients. Early measurement of serum LDH can be used in identifying a group of standard risk ALL patients with a high relapse hazard ${ }^{7}$. Serum LDH is almost certainly produced by the tumor cell. Its concentration rises during tumor growth. Serum LDH level has significant correlation with total tumor burden ${ }^{8}$. There is a good relationship between serum LDH level and the course of neoplasia and the degree of dissemination of the neoplastic process. The patient with neoplasia, serum LDH level correlates with the response to therapy 9 . Following induction serum LDH level 
decreases and when tumor growth resumes as the patient relapse from therapy serum $\mathrm{LDH}$ level rises again. Estimation of serum LDH may be helpful in evaluating the response to therapy ${ }^{10}$.

Serum LDH level which may reflect the mass of tumor present and it is lowest in patient with localized disease. High proliferation with high cellular turnover rate could explain the markedly elevated levels of serum LDH in untreated patient with large tumor. Serum LDH level estimation not only serves as an enzymatic indicator or mass of the tumor but also has prognostic significance for prolonged disease free survival $^{11}$. A definite and consistent shift in the pattern of molecular form of $\mathrm{LDH}$ has been found in a large series of malignant human neoplasm as compared with benign tumors and normal controls ${ }^{12}$. Serum LDH activity approximate to normality when the tumor regression is near completion so that its reliability as an indicator is evident. The LDH activity of serum increases promptly after the tumor transplantation and decreases with tumor regression ${ }^{13}$.

Till now, there is no such study of serum LDH level estimation as an enzymatic tool for presumption of childhood ALL and the response to chemotherapy during induction of remission in Bangladesh. But it is proposed that serum LDH measurement is a dependable tool for diagnosis and prognosis of childhood ALL. As the estimation of serum LDH is easy, readily available and economic, therefore, this study was conducted to evaluate that serum $\mathrm{LDH}$ level is a dependable tool in the presumption and the response to chemotherapy during induction of remission in childhood ALL.

\section{Materials and Methods}

This case control prospective study was carried out in 44 cases of ALL and 25 controls of both sexes, age ranging from 1 to 15 years during the period from January to December 2004. The subjects were stratified into diagnosed case of ALL who did not have any sign of hemolysis, were not severely sick and did not receive any previous chemotherapy. Control cases were those who did not suffer from any kind of illness.

The diagnosis of every ALL patient was made on the basis of clinical manifestation, complete blood count, peripheral blood film and the findings of bone marrow aspirate. Serum LDH level was estimated by using the kits based on photometric system by microflow cell photometer, RA-50 Chemistry system. The peripheral blood films and bone marrow aspirate for morphological study were stained with Geimsa; for cytochemistry of bone marrow aspirate was stained with Periodic Acid Schiff (PAS) and viewed under high power lenses primarily on the basis of light microscope and in the more difficult cases immunophenotyping were performed. Then, following proper hydration with 3 liter $/ \mathrm{m}^{2} /$ day of intravenous fluid and alkanization, protocol based (UKALL-X) induction was given with vincristine $1.5 \mathrm{mg} / \mathrm{m}^{2}$ intravenously weekly for 4 weeks, IT (methotrexate $12.5 \mathrm{mg}+$ hydrocortisone $25 \mathrm{mg}$ ) weekly for 4 weeks, donomycin 45 $\mathrm{mg} / \mathrm{m}^{2}$ day 1 and day 2 intravenously, Lasparaginase $6,000 \mathrm{IU} / \mathrm{m}^{2}$ deep intramuscularly every alternate day from $3^{\text {rd }}$ day 12 doses, prednisolone $40 \mathrm{mg} / \mathrm{m}^{2}$ first 4 weeks of induction orally, allopurinol $100 \mathrm{mg} / \mathrm{m}^{2}$ first 2 weeks of induction orally, sodium bicarbonate $100 \mathrm{mg} / \mathrm{m}^{2}$ first 2 weeks of induction orally.

Presumption and the response to induction of remission in childhood ALL was assessed by measuring serum LDH level on admission, day 14 and day 29 of induction. Serum LDH level and the peripheral blood film were performed in control cases when they came for check up. Serum LDH level of ALL on admission was correlated with the LDH level of control. LDH level was also correlated with the hematological parameters and bone marrow blast cell percentages at admission, day 14 and day 29 of induction in ALL.

Collected raw data were organized into a statistical format and appropriate statistical analysis was done. All continuous data were expressed as mean $\pm \mathrm{SD}$ and the categorical data in percentage. The values were analyzed statistically with paired " $\mathrm{t}$ " test, correlation co-efficient " $r$ " test. " $p$ " value of $<0.05$ was taken as the minimum level of significance.

\section{Results}

The mean ( \pm SD) serum LDH level in ALL at admission and control at check up were $2091.98 \pm$ 1073.20 and $362.32 \pm 89.69 \mathrm{U} / \mathrm{l}$ respectively. It was about almost six time the control value $(\mathrm{p}<0.001$; Table I).

The total WBC count and serum LDH level in ALL on admission, day 14 and day 29 of induction were $121306.82 \pm 141005.02,15002.27 \pm 14208.08$ and $8047.73 \pm 7372.21 / \mathrm{mm}^{3}$ respectively and $2091.98 \pm$ 1073.20, $561.43 \pm 266.24$ and $701.70 \pm 420.17 \mathrm{U} / \mathrm{l}$ respectively. Total WBC count was significantly decreased along with the serum LDH level at day 
14 and day 29 of induction from admission $(\mathrm{p}<0.001)$.

On admission, day 14 and day 29 of induction in ALL mean \pm SD of platelet count were $72272.73 \pm$ 57176.33, $67795.45 \pm 39949.14$ and $84136.36 \pm$ $47897.94 / \mathrm{mm}^{3}$ respectively. There was significant rise of platelet count observed at day 29 of induction from admission in relation to significant decrease level of serum LDH $(p<0.001)$.
In ALL mean \pm SD of peripheral and bone marrow blast cell on admission, day 14 and day 29 of induction were $62.27 \pm 26.80,4.02 \pm 5.27$ and 1.36 $\pm 2.65 \%$ respectively and $45.95 \pm 17.08,18.34 \pm$ 8.47 and $9.98 \pm 11.53 \%$ respectively. Serum LDH level was significantly decreased along with the peripheral and bone marrow blast cell percentages at day 29 of induction from admission $(\mathrm{p}<0.001)$.

Table I: Correlation between serum LDH level and hematological parameters on admission, day 14 and day 29 of induction in ALL

\begin{tabular}{|c|c|c|c|c|c|c|c|}
\hline $\begin{array}{l}\text { Time of } \\
\text { estimation }\end{array}$ & $\begin{array}{l}\text { Serum LDH (U/l) } \\
\text { Mean } \pm \text { SD }\end{array}$ & $\begin{array}{c}\text { Platelet } / \mathrm{mm}^{3} \\
\text { Mean } \pm \text { SD }\end{array}$ & $\mathrm{p}$ value & $\begin{array}{l}\text { Peripheral blast } \\
\text { cell }(\%) \\
\text { Mean } \pm \text { SD }\end{array}$ & $\mathrm{p}$ value & $\begin{array}{l}\text { Bone Marrow } \\
\text { blast cell (\%) } \\
\text { Mean } \pm \text { SD }\end{array}$ & $\mathrm{p}$ value \\
\hline On admission & $2091.98 \pm 1073.20$ & $72272.73 \pm 57176.33$ & $>0.05$ & $62.27 \pm 26.80$ & $>0.05$ & $45.95 \pm 17.08$ & $>0.05$ \\
\hline $\begin{array}{l}\text { At day } 14 \text { of } \\
\text { induction }\end{array}$ & $561.43 \pm 266.24$ & $67795.45 \pm 39949.14$ & $>0.05$ & $4.02 \pm 5.27$ & $>0.05$ & $18.34 \pm 8.47$ & $>0.05$ \\
\hline $\begin{array}{l}\text { At day } 29 \text { of } \\
\text { induction }\end{array}$ & $701.70 \pm 420.17$ & $84136.36 \pm 47897.94$ & $<0.001$ & $1.36 \pm 2.65$ & $<0.001$ & $9.98 \pm 11.53$ & $<0.001$ \\
\hline
\end{tabular}

N.B: Serum LDH level was correlated with each hematological parameter on the respective day

\section{Discussion}

In our study on admission, the mean range of serum LDH level was about six times more than control. These findings are consistent with the observations of Kornberg and Polliack (1980), when they showed that marked elevations of serum LDH level are highly suggestive of acute leukemia of lymphoblastic type ${ }^{4}$. Increased cellular LDH activity reflects a shift towards anerobic metabolism and increased glycolysis in the cytoplasm of malignant cells accompanied by high cellular turnover rate, two separate study performed by Stuart et al., $1970^{16}$ and Field et al., $1966^{19}$.

Our results are similar to those obtained by Stuart et al. $1970^{16}$. Sector et al., $1960^{17}$, and Bierman et al., $1957^{18}$, when they found increased serum LDH activity in isolated lymphoblasts and in the serum of patients with ALL and in animals with transplantable lymphatic leukemia. In contrast to the above data and the findings of this study, Bierman et al., reported the elevated levels in 47 of 54 patients with lymphatic leukemia and in all patients with the myeloid leukemia and $86 \%$ of patients with malignant lymphoma.

Though serum LDH level was significantly decreased at day 14 and day 29 of induction from admission but at day 29 of induction the level was somewhat higher, this was because of 6 (13\%) patients not responded to usual doses of chemotherapy because of the individual biology of cancer cell are different. With increasing genetic instability due to decreasing cell cycle control mechanism, the malignant cell may acquire additional characteristics of invasiveness and decrease sensitivity. Basing on a better under standing of the cancer cells new therapeutic approaches can now be tested reported by Wagner, $2001^{20}$, but the rest $38(87 \%)$ patients undergone complete remission. This observation had similarities with the findings of Erickson and Morales, 1961, when they showed that with exacerbations in patients under treatment for leukemia the level of serum $\mathrm{LDH}$ raises again ${ }^{5}$.

Though there was no significant rise of platelet count observed at day 14 of induction, as bone marrow was infiltrated with the blasts cell, but because of lympholysis following chemotherapy there was significantly raised level of platelet at day 29 of induction from admission in relation to significant decrease level of serum LDH $(p<0.001)$. These findings are consistent with the findings of West et al., 1958, when they found that following treatment with chemotherapeutic agents serum LDH levels were decreases ${ }^{14}$. Theses observations also had similarities with the study of Erickson and Morales 1961, when they proved that estimation of serum LDH level has prognostic value during induction of remission ${ }^{15}$.

On admission and day 14 of induction, there was no significant correlation found between the peripheral and bone marrow blasts cell percentages with serum LDH level but a significant decrease value of both peripheral and bone marrow blast cell 
percentages were observed along with the significant decrease level of serum $\mathrm{LDH}$ at day 29 of induction from admission $(\mathrm{p}<0.001)$. These findings were consistent with the observations of Kornberg and Polliack (1980), when they found that the elevated serum LDH levels may relate more to the total leukemic cell mass than to the number of circulating blasts. However, in individual patient with ALL, a good correlation was found during cytotoxic treatment, remission and relapse ${ }^{4}$.

In conclusion, this study suggests that serum LDH level estimation can be accepted as an enzymatic tool for presumption of childhood ALL and the response to chemotherapy during induction of remission.

\section{References}

1. Gupte S. Pediatric oncology. In: The short textbook of pediatrics. $9^{\text {th }}$ ed. New Delhi, Jaypee Brothers, 2001, pp 438-51.

2. Veerman AJP. Acute lymphoblastic leukemia in children: Experiences in West and East. Bangladesh J Child Health 2003; 27: 16-17.

3. Mannan MA. Pediatric oncology Bangladesh- The long safari. Bangladesh J Child Health 2003; 27: 34-35.

4. Kornberg A, Polliack A. Serum lactic dehydrogenase levels in acute leukemia: Marked elevations in lymphoblastic leukemia. Blood 1980; 56: 351-55.

5. Erickson RJ, Morales DR. Clinical use of lactic dehydrogenase. New Engl J Med. 1961; 265: 478-82.

6. Magrath IT. Malignant non-Hodgkin's lymphomas. In: Principle and practice of pediatric oncology. Pizo PA, Poplack DG (eds). $4^{\text {th }}$ ed. Philadelphia, Lippincott William and Wilkins, 2002, pp 661-705.

7. Pui CH, Dodge RK, Dahl GV, Rivera G, Look AT, Kalwinsky D, Bowman WP, Ochs J, Abromowitch M, Mirro J. Serum lactic dehydrogenase level has prognostic value in childhood acute lymphoblastic leukemia. Blood 1985; 66: 778-82.

8. Magrath I, Lee YJ, Anderson T, Henle W, Ziegler J, Simon R. Prognostic factors in Burkitt's lymphoma. Cancer 1980; 45: 1507-15.
9. Wroblewski F. The significance of alterations in lactic dehydrogenase activity of body fluids in the diagnosis of malignant tumors. Cancer 1959; 12: 27-39.

10. Brindley CO, Francis FL. Serum lactic dehydrogenase and glutamic oxaloacetic transaminase correlations with measurements of tumor masses during therapy. Cancer 1963; 23: 112-17.

11. Arseneau JC, Canellos GP, Banks PM, Berard CW, Gralnick HR, Jr Devita VT. American Burkitt's lymphoma: A clinicopathologic study of 30 cases. Am J Med. 1975; 58: 314-21.

12. Goldman RD, Kaplan NO, Hall TC. Lactic dehydrogenases in human neoplastic tissues. Cancer 1964; 24: 389-99.

13. Hsieh KM, Suntzeff V, Cowdry EV. Serum lactic dehydrogenase activity as indication of neoplastic growth and regression. Proc Soc Exp Biol Med. 1955; 89: $627-29$

14. West M, Heller P, Zimmerman HJ. Serum enzyme in disease. Ill Lactic dehydrogenase and glutamic oxaloacetic transaminase in patients with leukemia and lymphoma. Am J Med Sci. 1958; 235: 689-701.

15. Erickson RJ, Morales DR. Clinical use of lactic dehydrogenase. New Engl J Med. 1961; 265: 531-34.

16. Stuart J, Simpson JS, Mann JR. Intracellular hydrogen transport system in acute leukemia. $\mathrm{Br} \mathrm{J}$ Haematol. 1970; 19: 739-48.

17. Sactor B, Dick AR. Alpha-glycerophosphate and lactic dehydrogenase of hemopoetic cell from leukemic mice. Cancer Res. 1960; 20: 1407-12.

18. Bierman HR, Hill BR, Reinhardt L, Emory E. Correlation of serum lactic dehydrogenase activity with the clinical status of patients with cancer, lymphomas and leukemias. Cancer Res. 1957; 12: 660-67.

19. Field M, Block JB, Levin R, Rall DP. Significance of blood lactate elevations among patients with acute leukemia and other neoplastic proliferative disorders. Am J Med. 1966; 40: 528-47.

20. Wagner HP. Biology of cancer cells. In: International seminar and CME program on pediatric hematology and oncology. $1^{\text {st }}$ international Society of Pediatric Oncology (SIOP). Dhaka, Bangladesh, 2001. 